\title{
The Internationalization of Chinese Firms: A Critical Review and Future Research*
}

Ping Deng

Cleveland State University, p.deng@csuohio.edu

Follow this and additional works at: https://engagedscholarship.csuohio.edu/bus_facpub

Part of the Business Commons, and the Law Commons

How does access to this work benefit you? Let us know!

Publisher's Statement

This is the accepted version of the following article: Deng, P. (2012). The Internationalization of Chinese Firms: A Critical Review and Future Research*. International Journal Of Management Reviews, 14(4), 408-427. doi:10.1111/j.1468-2370.2011.00323.x, which has been published in final form at http://onlinelibrary.wiley.com/doi/10.1111/j.1468-2370.2011.00323.x/abstract

\section{Original Published Citation}

Deng, P. (2012). The Internationalization of Chinese Firms: A Critical Review and Future Research*. International Journal Of Management Reviews, 14(4), 408-427. doi:10.1111/j.1468-2370.2011.00323.x

This Article is brought to you for free and open access by the Monte Ahuja College of Business at EngagedScholarship@CSU. It has been accepted for inclusion in Business Faculty Publications by an authorized administrator of EngagedScholarship@CSU. For more information, please contact library.es@csuohio.edu. 


\title{
The Internationalization of Chinese Firms: A Critical Review and Future Research
}

\author{
Ping Deng \\ Professor and Eastern Scholar, Shanghai Lixin University of Commerce, China, \\ and Maryville University of St. Louis, St. Louis, MO 63141, USA \\ Corresponding author email: pdeng@maryville.edu or pdeng8@hotmail.com
}

\begin{abstract}
The important phenomenon that the internationalization of Chinese firms (ICF) represents has attracted increasing interest from scholars from multiple fields over the past 20 years (1991-2010). Although this proliferation of research has the potential to significantly improve understanding of Chinese multinational enterprises (MNEs), the necessary step of consolidating and integrating extant knowledge is absent. This paper reviews the scholarship on the ICF and offers insights into the specific areas in critical need of further development. By focusing on articles published in major scholarly journals during the period 1991-2010, the authors develop a coherent framework to organize and review conceptual and empirical findings from disciplines as far ranging as management, international business, cross-culture and area studies. Within the reviewed literature, three primary streams of enquiry are identified which focus on the antecedents, processes and outcomes of the ICF. Achievements within each of the three research streams are carefully reviewed using content analysis, whereby a number of important issues are identified which have remained consistently untouched, and recommendations are provided for future research, aimed at developing a more integrated research agenda on the ICF for management and international business scholars.
\end{abstract}

The author gratefully acknowledges the three anonymous reviewers and the Associate Editor, Dr Kamel Mellahi, for their valuable comments and critical suggestions on early versions of this manuscript. The author is also grateful to all the team members at the Eastern Scholar Research Team of International Trade at Shanghai Lixin University of Commerce for their valuable inputs and excellence research assistance. This research was supported in part by the Program for Professor of Special Appointment (Eastern Scholar) at Shanghai Institutions of Higher Learning. A previous version of the paper was presented at the 2010 Academy of Management (AOM) Annual Meeting, 6-10 August, Montreal, Canada. It was judged as one of the best papers and appeared in the 2010 AOM Best Paper Proceedings. It was also awarded Douglas Nigh Memorial Best Paper Award Finalist by the International Management Division of the AOM.

\section{Introduction}

In recent years, a significant development within the broad globalization trend has been the active role played by Chinese firms which are looking for opportunities to expand around the world. Thanks to the recent acceleration, outward foreign direct investment (OFDI) from China has risen at a compound average growth rate of $66 \%$ from 2002 to 2008 , so that, in 2008, China's OFDI stock totaled $\$ 184.0$ billion, while investment outflows reached $\$ 55.9$ billion (MOFCOM 2009). Such rapid internationalization of Chinese firms (ICF) in global markets has drawn the academic literature to explore this new important phenomenon and write about its development and its impact on Chinese growth, the world economy and future prospects (e.g. Alon and McIntyre, 2008; UNCTAD 2006). So far, research on the ICF, although 
prolific, has been conducted on a piecemeal basis. Theoretically, although researchers increasingly adopt a resource-based view (RBV) of the firm and institutional theories in research on Chinese international expansion, the research findings remain fragmented and disconnected.

It is imperative to synthesize the conceptual developments and diverse empirical findings towards a more integrated understanding of the entire process of the ICF. The objectives of this paper are: (1) systematically to evaluate the theoretical and empirical development of the ICF; (2) to propose a research model incorporating antecedents, processes and consequences of the ICF so as to identify the specific areas in critical need of further development; and (3) to provide recommendations for future research aimed at developing a more integrated research agenda on the ICF for management and international business (IB) scholars. The tasks are important for several reasons: (1) a timely synthesis and consolidation of extant knowledge contributes to the basis of theory extension and building in the area of internationalization (Bruton and Lau 2008; Macpherson and Jones 2010; Werner 2002); (2) the identification of key elements in the ICF provides a framework for future research and encourages cross-comparison of research findings (Barney and Zhang 2009; Child 2009); and (3) the component factors of the ICF identified and the research model proposed in this study can be adopted and further developed in the context of other emerging economies (Mellahi and Sminia 2009; Yang et al. 2006).

This paper is organized as follows. First, it identifies a set of refereed English-language journals, mainly in the disciplines of business and management, that publish China-related research over the 1991-2010 period (not including those online early publications). Second, from these academic journals, it develops a comprehensive database of articles related to the ICF over the last two decades. Third, by means of a qualitative content analysis, the research issues and key conclusions of these studies are analyzed and classified into three categories: antecedents, processes and outcomes so as to facilitate a synthesis and critique of existing contributions and to identify significant opportunities for future research. The paper begins with the antecedents of the ICF, including firm-level, industry-level, transaction-specific and institutional factors. It then reviews various processes and operations offered by the literature, followed by the research focusing on outcomes of the ICF. Drawing on the above sub- stantive and robust literature review, gaps in the literature are clarified and some key areas for future research are suggested.

\section{Research methods and overview}

To reflect the parameters of this review and also to be consistent with previous mainstream review articles on similar topics (Peng et al. 2001; Tsui et al. 2007), we focused on peer-reviewed English-language journal articles, excluding books, edited volumes, book chapters, teaching cases and other non-refereed publications from the sample, because journal articles can be considered validated knowledge and are likely to have the highest impact on the field (Armstrong and Wilkinson 2007; Judge et al. 2007). To ensure comprehensive coverage of the literature across different scholarly fields, we also considered four key factors when choosing the journals to be included in the substantive review. First, we sought to include business, management and IB journals that previous studies of levels of influence indicated were in the mainstream (Peng et al. 2001; Werner 2002). Second, we included journals emphasizing international and cross-cultural research that contributes to understanding of China's global business (Tsui et al. 2007; Wong and Chan 2003). Third, given that research on the ICF appeared initially in area studies journals (Frost 2004; Hong and Sun 2006), we included leading China-related journals. Finally, we also included top scholarly practitioner journals which are grounded in strong scholarship to draw practical implications (Agyenim et al. 2008; He and Lyles 2008).

We began with a keyword search using various electronic databases (Business Source Premier Publications, ProQuest/ABI and JSTOR) for the literature search, supplemented by manually going through all issues of the relevant journals. The keywords include 'China', 'Chinese firms', 'international expansion', 'globalization', 'cross-border mergers and acquisitions' (M\&As) and 'internationalization'. To be included in the review, an article had to address theoretical or empirical (either quantitative or qualitative) issues directly on the topics of China's IB, specifically at the firm or strategy level. In addition, for definitional rigor regarding what internationalization is, we define it as 'the crossing of national boundaries in the process of growth' (Buckley and Ghauri 1999, p. ix), referring to 'outward internationalization', which is realized 
mainly through cross-border M\&As and greenfield investment outside China by Chinese multinational enterprises (MNEs). As a result, we exclude 'inward internationalization', which is fulfilled mainly through original equipment manufacturing or joint venturing (JV) in China. Furthermore, since the review focuses on the firm-level business activities, we define Chinese firms or MNEs as China-based international companies which 'are engaged in outward FDI, where they exercise effective control and undertake value-adding activities in one or more foreign countries' (Luo and Tung 2007, p. 402). Using this definition, we exclude overseas JVs minority-owned by Chinese firms, Chinese trade companies or state-owned enterprises (SOEs) whose roles are entirely to pursue political objectives designated by the Chinese Government. This systematic and rigorous review identifies a total of 121 articles on the ICF in 45 journals which meet the criteria for inclusion. In line with other substantive review articles (e.g. Bruton and Lau 2008; Tsui et al. 2007), even though every effort was made to be thorough in the search, the possibility remains that we might have unintentionally missed some articles. Table 1 lists the number of articles in each of the four types of journals published during the research period.

Two observations can be made from Table 1. The first concerns the publication dates. The table shows that only eight articles $(6.6 \%)$ were published in the first ten-year period (1991-2000), while 113 articles (93.4\%) were published in the second ten-year period (2001-2010). Among those published in the last decade, 21 articles were in the first five years (20012005), whereas 92 were in the most recent five years (2006-2010), representing $76 \%$ of the total publications on the ICF in the last two decades (1991-2010). This dramatic increase in the last five years is largely due to special issues on the internationalization of emerging market firms and particularly Chinese firms. These special issues were published by Journal of International Business Journal (JIBS) (July 2007), International Journal of Chinese Culture and Management (December 2008), Chinese Management Studies (January 2009), Industrial and Corporate Change (April 2009) and Journal of International Management (June 2010). Equally important, several other journals including Management and Organization Review and Journal of World Business also have forthcoming special issues on the globalization of Chinese enterprises. One interpretation is that special issues have been used to encourage scholarship in underrepresented important research areas (Macpherson and Jones 2010; Mellahi and Sminia 2009), indicating that research on the ICF is truly a new phenomenon of crucial importance.

A second and related observation from Table 1 shows a clear trend toward more publications particularly in areas of business and management over time, and the number of these articles appearing in top IB journals (i.e. JIBS and Journal of World Business) has begun to increase significantly during the last five years. So far, however, none of the research is yet published in mainstream, first-tier (arguably the most influential) management journals, including Academy of Management Review, Academy of Management Journal and Strategic Management Journal (Judge et al. 2007). This frequency analysis suggests that research on the ICF is still a very context-specific literature which has not yet achieved much academic legitimacy outside the immediate environment of IB journals. This may also suggest that the research still has not achieved the necessary theoretical rigor, particularly in terms of internal and construct validity (Eisenhardt 1989; Gibbert et al., 2008).

In addition, using content analysis, we also present a breakdown of 121 articles according to the research methods used, either empirical (quantitative or qualitative) or theoretical, as shown in Table 2. Among the 28 quantitative studies, 13 articles use survey or questionnaire data mainly at the firm level, whereas 15 articles use archival data sets at industry or country level. For the qualitative papers, while most articles use multiple case studies, there are seven single-case articles. However, the in-depth case studies tend to focus on a small number of prominent Chinese firms, including Haier, Huawei, Lenovo and TCL. Regarding the 72 conceptual or perspective papers, they are published in a whole range of journals, either focusing on macroeconomic analyses of outward foreign investment trends of Chinese firms and the role of Chinese Government or drawing policy implications of Chinese MNEs' emergence for host countries, both developed (particularly the US) and developing (particularly Africa and Southeast Asian nations).

In short, the 121 articles published in the peerreviewed journals over the period 1991-2010 provide a snapshot of extant research interests in China's IB. The increasing appearance of such studies in prestigious journals suggests their value to global scholarship on management and strategy, and this trend is most likely to continue as China becomes a dominant global economic actor and its enterprises emerge 
Table 1. Research on the internationalization of Chinese firms: number of journal articles

\begin{tabular}{|c|c|c|c|c|}
\hline Journal field and name & Subtotal & $1991-2000$ & $2001-2005$ & $2006-2010$ \\
\hline Business and Management & 62 & 2 & 8 & 52 \\
\hline Asia Pacific Journal of Management & 8 & & & 8 \\
\hline Journal of International Business Studies & 7 & & & 7 \\
\hline Journal of World Business & 7 & & & 7 \\
\hline Asian Business and Management & 5 & & 1 & 4 \\
\hline Industrial and Corporate Change & 5 & & & 5 \\
\hline Chinese Management Studies & 4 & & & 4 \\
\hline Journal of International Management & 4 & & & 4 \\
\hline European Management Journal & 4 & & 2 & 2 \\
\hline Multinational Business Review & 4 & & & 4 \\
\hline Asia Pacific Business Review & 3 & 1 & 2 & \\
\hline International Business Review & 2 & & 1 & 1 \\
\hline International Marketing Review & 2 & & & 2 \\
\hline Management International Review & 2 & 1 & & 1 \\
\hline Management and Organization Review & 2 & & 1 & 1 \\
\hline *Others & 3 & & 1 & 2 \\
\hline Scholarly Practitioner & 18 & 3 & 4 & 11 \\
\hline Thunderbird International Business Review & 5 & & 1 & 4 \\
\hline Business Horizons & 3 & & 1 & 2 \\
\hline NBR Analysis & 2 & & & 2 \\
\hline China Business Review & 2 & 1 & & 1 \\
\hline Transnational Corporations & 2 & 2 & & \\
\hline *Others & 4 & & 2 & 2 \\
\hline International and cross-culture & 22 & 1 & 4 & 17 \\
\hline Intl J. of Chinese Culture and Management & 6 & & & 6 \\
\hline J. of Chinese Economic and Business Studies & 5 & & 1 & 4 \\
\hline Pacific Affairs & 4 & & 1 & 3 \\
\hline Intl J. of Technology and Globalization & 2 & & & 2 \\
\hline World Development & 2 & & 2 & \\
\hline *Others & 3 & 1 & & 2 \\
\hline Area studies and miscellaneous & 19 & 2 & 5 & 11 \\
\hline China Quarterly & 5 & 1 & 1 & 3 \\
\hline China and World Economy & 2 & & 1 & 1 \\
\hline Asian Survey & 3 & 1 & & 2 \\
\hline Pacific Review & 2 & & 1 & 1 \\
\hline *Others & 7 & & 2 & 5 \\
\hline Total & 121 & 8 & 21 & 92 \\
\hline
\end{tabular}

* Others refer to 17 journals which published only one article on the ICF, including Harvard Business Review, Organizational Dynamics, Journal of Asian Business, Long Range Planning, Academy of Management Perspective, Pacific Economic Review, Canadian Public Policy, China: An International Journal, Europe-Asian Studies, Review of African Political Economy, Journal of Modern African Studies and European Geography and Economics.

Table 2. Content analysis of methodology of the ICF

\begin{tabular}{lccc}
\hline & Number of articles: 121 & & \\
\hline $\begin{array}{l}\text { Quantitative studies (survey or } \\
\text { archival data set) }\end{array}$ & Qualitative studies (single or & Conceptual or overview studies & Sultiple case-based) \\
$\begin{array}{l}28 \text { (Survey data: } 13 \text { and archival } \\
\text { data: } 15)\end{array}$ & $\begin{array}{c}\text { cases: } 14) \\
\text { (single case: } 7 \text { and multiple }\end{array}$ & 72 & 121 \\
\hline
\end{tabular}

onto the world center stage (Alon et al. 2009; Athreye and Kapur 2009).

For the purpose of achieving a solid analysis of the ICF research, we used the methodology of content analysis (Krippendorff 2004; Weber 1990). Based on a systematic and robust literature review, we classified the 121 articles by their research areas under three categories of analysis - antecedents, processes 
and outcomes - which emerged through the development of this research stream. In addition, in each of the three categories we also included several major themes, as shown in Figure 1. This content analysis allows key themes, trends and differences to be identified within different streams of the ICF to facilitate analysis of a large quantum of textual data, thereby facilitating the achievement of reliability and interpretative validity, both quantitatively (e.g. frequently counts, correlations, trends and differences over time) and qualitatively (e.g. theme identification, theory elaboration). In addition, within-theme and between-theme comparisons were used to identify and elaborate themes (Eisenhardt 1989). Conse-

Organizing framework derived from content analysis of the literature

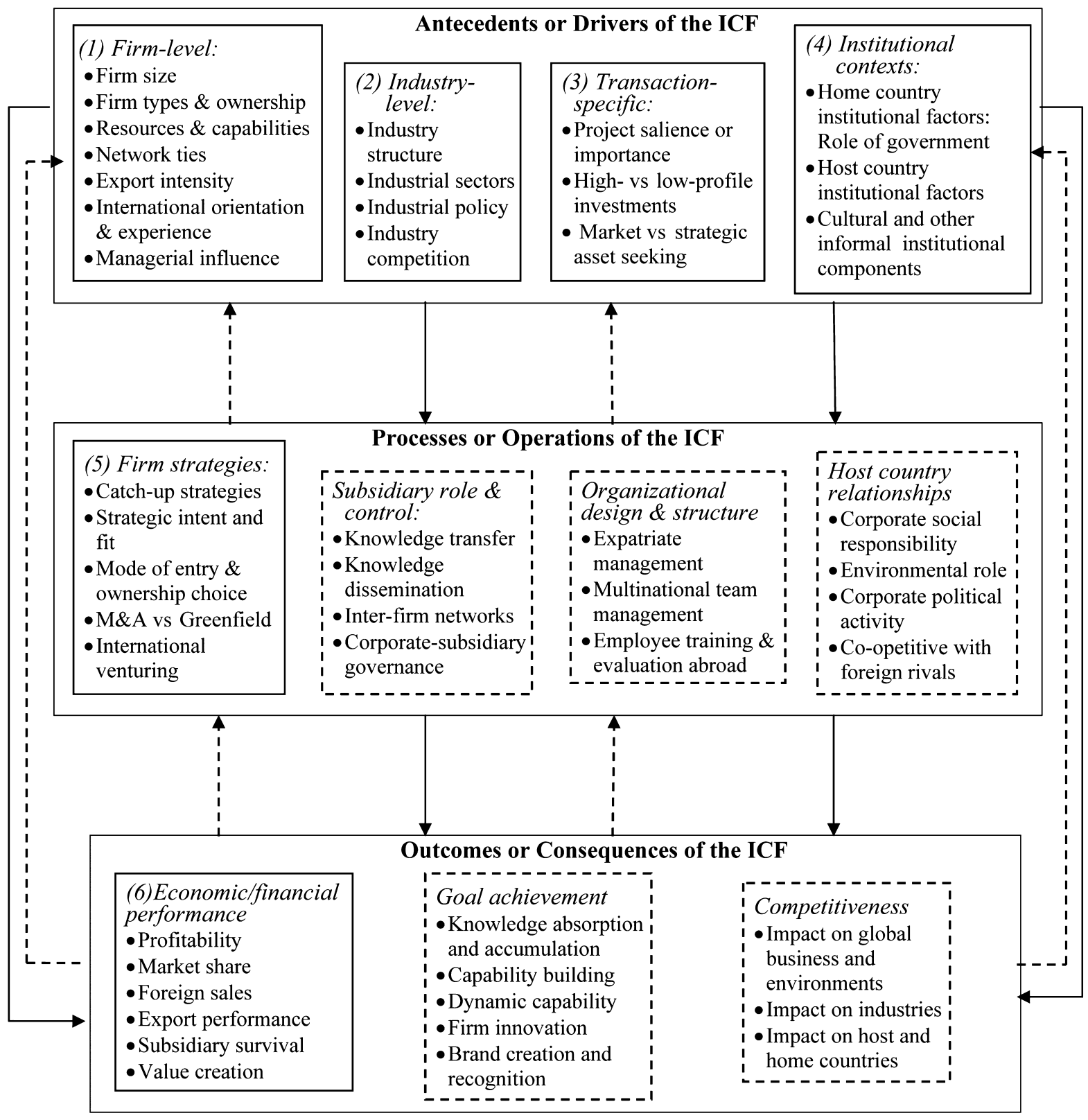

Figure 1. Note: The solid arrows and matrices indicate the causal (but not exact) connections between elements and the topics that extant studies have analyzed, whereas the dashed arrows and matrices represent those unexplored or significantly underinvestigated issues, which could provide fruitful research streams in the future, and they are discussed mainly in the section on directions for future research 
quently, the content analysis revealed that existing literature on the ICF clustered around six main themes under three categories of analysis: antecedents, processes and outcomes, as shown in the solid matrices of Figure 1.

Antecedents of Chinese internationalization include key themes related to (1) firm-level (2) industry-level, (3) transaction-specific and (4) institutional contexts. The key process in the ICF research focuses on (5) firm strategies. The key outcome of the Chinese internationalization research concentrates on (6) economic or financial performance. Accordingly, this review focuses on these six major themes surrounding the ICF. Moreover, Figure 1 shows that all four themes in the category of antecedents of the ICF were most frequently discussed, whereas three of the four themes in the category of processes and two themes in the category of outcomes, which are shown in the dashed matrices of Figure 1, were not sufficiently analyzed and/or are significantly under-investigated; they may provide promising research opportunities in the future, which will be carefully discussed in the section on 'Directions for future research'.

Given the integrated nature of many studies, the distribution among these themes appear somewhat arbitrary (see also Werner 2002; Yang et al. 2006). However, we believe that such an institutive organizing framework with a solid foundation of content analysis greatly helps this review to follow a logical structure, thoroughly represent the available research, and look at these issues holistically rather than piecemeal, so that readers will not 'miss the forest for the trees'. Limited by the page restriction of the journal, the following focuses on the articles derived from rigorous scientific methods, which are published mainly in business and management disciplines, and discusses the three components of the ICF that have been investigated or suggested in prior research and which could fruitfully be examined in future studies.

\section{Antecedents of ICF}

Given the high level of international activities of Chinese firms across the globe, a logical place to begin an inquiry of this phenomenon is with its antecedents. Research to date provides insight into four important streams of antecedents of the ICF: firm-level, industry-level, transaction-specific and institutional factors.

\section{Firm-level antecedents}

Firm-level antecedents of the ICF are the focus of scholarly work using one basic strategic assumption. Scholars assume that Chinese firms choose to engage in international activity to enhance the value or competitiveness of the firm, and that these choices depend largely upon firm-specific factors such as company size, ownership, export intensity and international experience. These firm-level factors have been largely verified by a number of recent empirical studies (e.g. Agyenim et al. 2008; Gao et al. 2010; Lau et al. 2010). The recent ascendance of the RBV of the firm (Barney 1991; Teece et al. 1997) as the predominant theory in studies on the ICF (e.g. Cui and Jiang 2009a; Deng 2007; Rui and Yip 2008) has heightened the firm-specific characteristics which factor prominently in this stream of research.

Firm size. Perhaps the most frequently examined firm-level antecedent of the ICF is firm size, whether measured by sales, assets or market share. Much of this work argues that larger Chinese firms are more internationally active, and firm size is an important antecedent of particular forms of ICF (Cui and Jiang $2009 b)$. Scholars focus on firm size for a variety of reasons. The foremost seems to be that firm size is a proxy for resources and provides some indication about a firm's ability to become internationally engaged. After all, 30 top Chinese firms accounted for $80.4 \%$ of the total amount of OFI in 2004, and this pattern continues to date (MOFCOM 2005, 2009). In addition, firms with greater financial and intangible resources are more likely to engage in international acquisitions or establish greenfield investment projects alone and compete on a global scale, while those with fewer resources are forced to work collectively with others or rely upon network assets (Lau et al. 2010; Yiu et al. 2007; Zhou et al. 2007).

Firm types and ownership. Firm type and ownership is an important indicator of the ICF. Based on ownership and the level of international diversification, Luo and Tung (2007) categorize Chinese MNEs into SOEs (including transnational agents and commissioned specialists) and non-SOEs (including niche entrepreneurs and world-stage aspirants), and each group has found a unique way to make inroads in the international arena. For example, China's world-stage aspirants such as Haier have become a formidable force in shaping the landscape of global 
competition, whereas the country's commissioned specialists such as China's Minmetals and Sinopec are simultaneously playing their dual roles of reaping the fruits of international expansion and completing the state-assigned mandate. Luo and Tung's typologies of Chinese MNEs are in line with Zeng and Williamson (2003)'s four groups of Chinese MNEs national champions, dedicated exports, competitive networks and technology upstarts - and each of them also tackles the global markets in unique ways. Research in this stream of inquiry also discusses differences between SOEs and non-SOEs in terms of overseas investing behaviors (Lin 2010). According to some scholars (e.g. Cui and Jiang 2009b; Voss et al. 2010), as the host country regulative institutional barriers are higher for SOEs than for nonSOEs, Chinese SOEs tend to choose JV entry mode to exchange ownership for legitimacy. However, state ownership can be considered a firm-specific advantage for Chinese SOEs, since they are most likely to get speedy government approval for foreign investments and favorable state incentives and support (Lin 2010; Morck et al. 2008). For the private Chinese firms or non-SOEs that decide to venture abroad, they are more likely to transcend home-based limits to growth since they face the monopolistic presence of large SOEs in certain sectors and state intervention in industrial policy (Luo et al. 2010; Voss et al. 2010).

Resources and capabilities. Another prominent firm-level antecedent is the firm's resources and capabilities. The underlying theoretical basis of this work is the RBV (Barney 1991; Teece et al. 1997), examining what ownership advantages Chinese firms possess and the impact upon the ICF. A consensus emerges in this line of research inquiry that the ownership advantages which Chinese firms enjoy are mainly network based (Frost 2004; Wu and Sia 2002; Zhou 2007) and/or home country based (Boisot and Meyer 2008; Rugman and Li 2007). Such relational assets account for their investment motive (i.e. to redress competitive disadvantage) and intra-regional expansion strategy (Rugman and Li 2007; Sethi 2009; Warner et al. 2004). Beyond regional expansion, Chinese MNEs are driven by their strategic need to build sustainable global competitiveness, especially by acquiring strategic assets overseas (Deng 2004, 2007; Rui and Yip 2008). It is clear that on the resource side, Chinese OFDI is both asset exploiting and asset augmenting (Luo and Rui 2009), and both transaction cost and strategic intents have an impact on the investing motivations and decisions (Wong and Chan 2003; Young et al. 1996).

Network ties. The most significant role of networks in emerging economies is the substitution for external markets (Khanna and Palepu 2006; Peng, 2003), and that argument is supported by several empirical studies on the ICF. For example, Yiu et al. (2007) highlight the important role of home country network ties in facilitating firms to pursue international venturing, and Zhou et al. (2007) verify that institutional networks help Chinese firms to cope better with the transitioning institutional environment. This kind of institutional relatedness is an essential asset for Chinese firms to mitigate information asymmetry overseas (Liu and Tian 2008; Yamakawa et al. 2008). Therefore, network assets provide additional ownership advantages, particularly for small-to-medium-sized Chinese firms to successfully venture abroad early or at a rapid pace, since they are normally weak business organizations with strong, locally based social networks (Lin 2010; Zhou 2007).

Export intensity. Other scholars focus on the relationship between export intensity and the ICF. For example, scholars such as Agyenim et al. (2008) and Gao et al. (2010) find that the greater the export level of a Chinese firm, the more likely the firm is to use an ongoing relational approach to international expansion. Moreover, as China is now adopting export-led economic growth policies, some scholars propose that a firm's export intensity as a direct or moderating variable is of particular relevance for Chinese firms in their decisions to venture overseas (Fetscherin et al. 2010; Liu et al. 2008). As another example, Cardoza and Fornes (2009) empirically analyze and verify that a firm's percentage of exports is positively correlated with the ICF.

International experience. Several antecedents linked to the ICF are related to a firm's international orientation and experience. In a recent case study of the Galanz Group, a highly successful Chinese manufacturer, Ge and Ding (2008) report that, with accumulation of international experiences, Galanz was more likely to have large cross-border investments. On top of that, international experience has often been used as a proxy for constructs such as 'visibility of the firm' (Cardoza and Fornes 2009; Lau et al. 2010), 'reputation' (Agyenim et al., 2008; Warner et al. 2004) and 'credibility' or 'intangible 
assets' (Deng 2007; Lu et al. 2010), all of which have been linked to the success of the ICF. Finally, several empirical studies (e.g. Liu et al. 2008; Zhou et al. 2007) observe a positive relationship between international experience and the ICF, as indicated by personal relationships formed over time between top managers and foreign subsidiaries or partners.

Managerial influence. The international orientation of top managers is another antecedent of the ICF with a behavioral focus, arguing that managerial orientation may be more important than the number of firm-specific resources in making strategic decisions such as OFDI (Carpenter et al. 2004; Hambrick and Mason 1984). Deng (2009) finds that Chinese firms tend to use top managers' domestic mindsets to scan international opportunities, and shows how large a role subjective, cognitive elements played in influencing a series of high-profile M\&A deals by Chinese MNEs. Several other studies (e.g. Ge and Ding 2008; Knoerich 2010; Teagarden and Cai 2009) also support the importance of the role of managerial interpretation of the ICF in their international expansion decisions. ${ }^{1}$ Based on in-depth studies of 16 Chinese privately owned firms, Liu and his colleagues (2008) argue that unique internationalization patterns of these firms are mainly determined by the 'bounded entrepreneurship' of the founders of this group of firms.

\section{Industry antecedents}

Compared with the large amount of scholarly work on the firm-level antecedents of the ICF, there are relatively fewer studies at the industry-level of analysis. However, the existing literature that explores either firm-level or industry-level antecedents of the Chinese internationalization does not differ much from the antecedents of traditional western MNEs. Most of the researchers who analyzed the ICF at the industry level concentrated on the issues of industry size, structure, policy and competition and their impact upon international activities of Chinese MNEs.

Industry structure. Several studies focus on the ICF at the industry-level of analysis (Bonaglia et al.

\footnotetext{
${ }^{1}$ We thank one of the reviewers who also made a valuable comment on managerial influence on the Chinese internationalization in terms of the increasing use of Chinese 'diasporas' in ICF.
}

2007; Niosi and Tschang 2009; Tolentino 2010). Their intent, almost exclusively, was to explore whether industry structural variables affected the industry's ability and propensity to internationalize from comparative perspectives. In addition, scholars (e.g. Niosi and Tschang 2009; Yang et al. 2009a) examined the relative position of a firm within an industry and found that domestic industrial leaders such as Haier, TCL and Lenovo are more likely to be engaged in international activities. Their findings are in line with the observations of Zeng and William (2003) and Morck et al. (2008), who report that the biggest companies in China by their OFDI are virtually those highly profitable SOEs with an officially sanctioned monopoly in some major industry. Finally, Yang et al. (2009b) draw a parallel between Porter's Five Forces Model of industry analysis and how industries determine international dynamics of Chinese and Korean firms.

Industrial sectors and policy. Firms in different industrial sectors are observed to show different international orientations, particularly for emerging economies (Fetscherin et al. 2010; Sutherland 2009). Using official project data, Buckley et al. (2008) find that the bulk of Chinese OFDI by value in the early to mid-1990s was in the tertiary and manufacturing sectors; historically, Chinese FDI in services has generally involved small-scale investments in trade-supporting activities. However, using official MOFCOM data, Taylor (2002) report that the manufacturing sector accounted for only $11.5 \%$ of China's OFDI in the late 1990 s, compared with $19.4 \%$ for resource development and extraction, and $66.4 \%$ for other categories (MOFCOM 2005; Zhan 1995). Finally, it is clear from these data that investment in the extractive industries is an important contribution to Chinese OFDI, especially in mining, fisheries and forestry exploitation and petroleum and natural gas exploration. However, regular reclassification and procedural revisions to the reporting of OFDI by activity on the part of MOFCOM make it difficult to draw systematic conclusions regarding changes to the sectoral distribution of Chinese OFDI (Buckley et al. 2008; Schuler-Zhou and Schuller 2009).

Industry competition. Several scholars have looked at how the domestic competition affects Chinese firms' international activity. For example, economic market liberalization gives a massive stimulus to Chinese firms to pursue OFDI (Liu et al. 2005; Yang et al. 2009b). However, some scholars (e.g. Niosi and 
Tschang 2009; Nolan and Zhang 2002; Teagarden and Cai 2009) contend that escaping home market saturation and ruthless price wars is of particular relevance for Chinese firms in their international decisions. Studying internationalization and technological catching up of Chinese and Indian consumer electronic giants, Duysters et al. (2009) find that competitors regularly closely watch each other's international patterns. Bonaglia et al. (2007) and Mathews (2009) also present evidence of a crowding effect on globalization around certain issues, suggesting that intra-industry dynamics plays an important role in the ICF. Similarly, several scholars (e.g. Mathews 2009; Sauvant 2005) show how firms from the BRIC countries (Brazil, Russia, India and China) both competed and co-operated with rivals to gain favorable political outcomes, and their arguments partially support an ambidexterity perspective on the ICF, as argued by Luo and Rui (2009); specifically, Chinese MNEs build and develop their co-opetitive (simultaneous co-operation and competition) ties so as to offset their late-mover disadvantages in the global marketplace.

\section{Transaction-specific antecedents}

A number of scholars also posit transactional characteristics as key antecedents of the ICF. With firm- and industry-level antecedents of the ICF as long-term and issue-spanning relationships, 'transactional' factors are more ad hoc and project or issue specific (Antkiewicz and Whalley 2007; Boisot and Meyer 2008). As firm-specific advantages also include transactional advantages, such as firms' capabilities to manage internal and external relationships, Morck et al. (2008) posit that Chinese SOEs have developed sophisticated measures which help them to expand into economies with similar institutional environments, so that they can achieve large returns on their outward foreign investment. Antkiewicz and Whalley (2007) and Li (2007) observe that the importance of an investment project to the company is one of the critical factors that motivates it to become internationally active. Boisot and Meyer (2008) report that Chinese firms gauge their international action largely by estimating the net impact on the firm's competitive performance and strategy, and they argue that, when the cost of crossing China's provincial borders exceeds the cost of crossing international borders, Chinese firms will internationalize at a relatively early stage of development. Furthermore, Cardoza and Fornes (2009) and Chen and Young (2010) find that SMEs from China pay increasing attention to high-profile cross-border M\&As, indicating the role of international project salience or importance to their respective firms' international expansion decisions.

\section{Institutional antecedents}

Research from institution theory argues that a firm's strategic choices are fundamentally influenced by both formal rules and informal cultural norms and values, both domestically and in host countries (North 1990; Oliver 1997; Wright et al. 2005). Given the extent of state control of the Chinese economy (Lieberthal and Herberg 2006; Wang 2002; Wu 2005), the institutional environment is likely to have had far-reaching effects on the ICF. Accordingly, researchers increasingly use institutional theory as the predominant perspective to explore how homecountry institutions and particularly the role of the Chinese Government act as the driving forces of the ICF (e.g. Deng 2009; Yamakawa et al. 2008; Yang et al. 2009a).

Home country institutional context. Within China, a large stream of institutional studies examine Chinese Governmental characteristics in explaining the ICF and predominantly their investment motivations (e.g. Deng 2004; Luo et al. 2010; Yang et al. 2009a; Zhan 1995). The basic assumption of these scholars is that the Chinese Government role may help to lay the foundation for the ICF (Child and Rodrigues 2005; Wang 2002). To illustrate, extant research portrays Chinese OFDI up to the early 1990 s as having been directed by government towards supporting export, providing resource supply and acquiring high technology (Cai 1999; Zhan 1995). Moreover, Chinese SOEs may not be profit maximizers or may be maximizing subject to government-guided influences, and China's preference to invest in developing countries may indicate a different model of investment behavior arising from state policy (Kim 2006; Lieberthal and Herberg 2006; Wu 2005). On top of that, many Chinese MNEs have been able to build a strong international competitive base through gaining strong government support for their international acquisitions, including substantial monetary support from state-controlled banks such as EXIM (Luo et al. 2010; Wang 2002; Warner et al. 2004). However, some Chinese firms may face negative discrimination and regulatory constraints in a transitional socialist market system (Globerman and Shapiro 2009; Tsui 
et al. 2004; Wu and Seah 2008). As a consequence, investing overseas may be non-SOEs' escape response to the restrictive business environment in China (Voss et al. 2010; Witt and Lewin 2007). Furthermore, institutional forces embedded in national environments and decision makers' cognitive constraints may be counted as a critical factor that helps lay the foundation for their cross-border M\&A strategies (Deng 2009; Liu et al. 2008). Finally, Buckley and his colleagues (2007) empirically show that there is 'a correlation between a key policy change and a change in the amount on distribution of Chinese ODI, or both' (p. 503) and capital market imperfections and institutional factors in China 'may have induced a perverse attitude to risk' (p. 510).

Host country institutional context. Another institutional effect is the host country environment. When Chinese MNEs attempt to venture into unfamiliar markets in another region (e.g. African and Latin America), acquisitions are preferred because acquisitions of existing operations facilitate risk minimization, experience building and major subsequent investments in the host region (Yeung and Liu 2008). From an institutional theory perspective, the attaining of institutional legitimacy is an important factor for firms facing restrictive host regulation and high cultural barriers (He and Lyles 2008; Scott 2001; Yang 2009). Yang (2009), for instance, examines whether isomorphism and mimetic, coercive and normative mechanisms apply to cross-border M\&As initiated by Chinese firms, and finds that not all M\&A decisions react to forces of conformity in the same way; overtime, the overall degree of conformity in M\&As decreases. Moreover, Chinese firms are more likely to seek investment opportunities in environments that resemble their home environment as the experience of operating in a highly regulated and controlled domestic environment may have equipped them with the special ownership advantages needed to be competitive there (Alden and Davies 2006; Gebre-Egziabher 2007). However, investment decisions of Chinese MNCs are apparently influenced by the home environment. When investing abroad, Chinese firms adjust their entry strategies to attain regulative and normative institutional legitimacy in host countries, and simultaneously need to comply with the rules set by the Chinese Government (Liou 2009; Obi, 2008). These strong dual impacts from both the host and home-country institutional environments show the uniqueness of OFDI from China (Child and Rodrigues 2005; Cui and Jiang 2009b).
Cultural or other informal institutional factors. Some scholars (e.g. He and Lyles 2008; Liu and Tian 2008; Wu and Sia 2002) explore the relationship between cultural factors in host countries and the ICF. Overall, they argue that more familiar cultures in host countries continue to help promote Chinese OFDI. In earlier phases of internationalization, it is evident that Chinese firms show a preference to go to countries where ethnically based social networks are present (Cai 1999; Sethi 2009; Young et al. 1998). Importantly, cultural proximity is found to be a significant factor in the ICF, and such variables do not change over time (Buckley et al. 2007; Yuan and Pangarkar 2010).

\section{Processes of ICF}

Compared with the volume of research on antecedents of the ICF, perhaps the area of research in the ICF that has received the least attention is what we term 'internationalizing to implement', referring to those efforts to better understand corporate internal resources and capabilities and external institutional environments related to effective implementation of the ICF (Deng 2009; Oliver 1997). Prominent recent work on the processes of the ICF is on firm international strategies, whereas other important process and implementation elements, including organizational structure, subsidiary role and control, and host country relationship are largely ignored. Nevertheless, a systematic study of these process issues is desperately needed and crucially important.

Catch-up strategies. At the broadest level of firm strategies, March (1991) differentiate between two fundamental behaviors: exploitation and exploration. International 'exploiting' includes investing abroad to generate more rents out of firm-specific advantages. International 'exploration', in contrast, is a more proactive and aggressive form of strategy. It includes such activities as enhancement of competitive positions and closely resembles 'catching-up' strategies, which account for the rapid upsurge of a number of Asian MNEs (Bruton and Lau 2008; Mathews 2009). The majority of scholars contend that international exploration should be considered part of an overall 'catching-up' strategy to assist Chinese firms to build up global competitive positions. For example, Rui and Yip's (2008) strategic intent perspective on overseas acquisitions by Chinese firms argues that their ultimate strategic goal is to gain sustainable competitive advantage and 
become a global player. Moreover, several scholars (e.g. Deng 2004; He and Lyles, 2008) provide institutional and/or cultural evidence for the argument that Chinese firms go abroad primarily to enhance a firm's critical competencies rather than to exploit existing firm-specific assets (Child and Rodrigues 2005; Luo and Tung 2007). Similarly, Luo and Rui (2009) present an ambidexterity perspective, highlighting Chinese MNEs' unique strategic behaviors of offsetting their late-mover disadvantages. Other scholars (e.g. Bonaglia et al. 2007; Li 2007) further demonstrate how Chinese MNEs pursued global growth through accelerated international expansion via linkage, leveraging and learning. However, there is wide variety in the salience of investment issues in the ICF, and 'exploration' may be quite different, depending on the nature of the investment or acquisition (Hong and Sun 2006; Tolentino 2010; Wu 2005). Therefore, a promising research question could be whether the current state of strategy taxonomies between 'exploitation' and 'exploration' is sufficient to explain Chinese MNEs' strategic behaviors, particularly when they are driven simultaneously by different types of overseas investment motivations.

Strategic intent and fit. Strategic intent is one of the most important motivations for Chinese firms to go abroad, which is designed to extend beyond setting up the most efficient affiliate in a single market and to fulfill strategic goals set at the corporate level for the purpose of maximum overall performance (Deng 2007; Globerman and Shapiro 2009). The strategic intent argument seems appealing to Chinese MNEs, since even the so-called China's national champions (Zeng and Williamson 2003) lag far behind developed MNEs, which are competing with local firms fiercely in every sector in China (Nolan and Zhang 2002; Rugman and Li 2007). The pressure of foreign entrants into China means that they are under great time pressures to catch up on capabilities. Accordingly, Chinese firms put stronger emphasis on strategic intent than strategic fit when venturing overseas (Rui and Yip 2008; Wong and Chan 2003). However, the strategic intent perspective proposed by Rui and Yip (2008) might be pertinent in explaining the foreign acquisitions made by aggressive Chinese firms, but it might be more appropriate for researchers to incorporate both the strategic fit and strategic intent aspects so as to capture a big picture underlying different Chinese international expansion behaviors, including greenfield investment (Cui and Jiang 2009a; Herbert et al. 2007; Luo and Rui 2009).
Mode of entry and ownership. Strategic intent and fit can have an impact on the decisions that Chinese investors make on the choice of a FDI entry mode, and that is examined by a number of studies (e.g. Cui and Jiang 2009a; Lin 2010; Voss et al. 2010). Cui and Jiang (2009a) argue that the entry mode choice is primarily influenced by the variables related to the firm's strategic fit in the host industry and its strategic intent of conducting FDI; specifically, a Chinese firm prefers wholly owned subsidiary entry mode when it adopts a global strategy, faces severe industry competition and emphasizes asset-seeking purposes in its FDI. On top of that, entry mode choice can also be influenced by different types of Chinese firms. As Chinese SOEs face high regulatory institutional barriers, they are more like to choose JV entry mode to exchange ownership for legitimacy (Cui and Jiang 2010; Lin 2010).

$M \& A$ vs greenfield investment. Greenfield investment and acquisitions are two common organizational modes through which Chinese firms internationalize their operations (Child and Rodrigues 2005). M\&As have become increasingly commonplace as the means for Chinese MNEs to seek global reach (Antkiewicz and Whalley 2007; Globerman and Shapiro 2009; MOFCOM 2009; Sutherland 2009). They are primarily used to secure brands and technology quickly and enhance innovation and differentiation advantages (Deng 2009; Rui and Yip 2008). However, with the existing cost advantage, Chinese firms are more likely to use organic international expansion (Cardoza and Fornes 2009; Niosi and Tschang 2009; Soderman et al. 2008). Industrial and sector features also lead to different ways of organizing transnational operations. For example, large Chinese oil and gas companies tend to make aggressive acquisitions because of the resource scarcity and historically global competitive patterns, and this approach escapes from the transaction cost premises and highlights the special characteristics of Chinese OFDI (Liou 2009; Obi 2008).

International venturing. Yamakawa et al.'s (2008) theoretical paper examines international efforts by new ventures from Chinese SMEs. Integrating the RBV and institutional theory, they formulate nine propositions regarding the internationalization of new ventures under varying conditions. Their conceptual analysis is evidenced by several empirical studies. Yiu et al. (2007), for example, show that the interaction between the institutional legacies of 
China and the dynamic capabilities of their corporate entrepreneurs is crucial for understanding international venturing of Chinese SMEs. Zhou et al. (2007) offer a social network explanation for the purported relationship between internationalization and firm performance in the context of Chinese-born global SMEs (see also Liu et al. 2008).

\section{Outcomes of ICF}

Internationalization itself may not have an ongoing positive performance effect, but the ability to implement international strategies successfully is closely intertwined with improving firm performance (Buckley and Ghauri 1999). Outcomes of the ICF can be measured and examined in three ways: (1) corporate goal achievement; (2) overall competitiveness; and (3) firm economic and financial performance. On top of that, the majority of articles published in international and area-studies journals focus on drawing government policy implications (Alden and Davies 2006; Lieberthal and Herberg 2006; Wu 2005). While performance studies are conducted mainly on Chinese firms, there is a small and growing body of research comparing Chinese firms with other emerging market, and particularly Indian, MNEs (Athreye and Kapur 2009; Sauvant 2005). Perhaps due to the difficulty in measuring ICF and isolating the internationalization effect on performance, the first two indicators of performance are seldom vigorously studied in the extant literature. Below, we discuss the third type of outcomes of the ICF (i.e. profitability, sales, market shares and value creations) in particular.

A lack of systematic official data makes it difficult to draw credible conclusions on the overall performance of the ICF (Buckley et al. 2008; Schuler-Zhou and Schuller 2009). Discussion of outcomes of the ICF is based largely on anecdotal evidence or self-framed interview results. However, scholars are beginning to pay increasing attention to examining the ICF effect on firm performance issues. By analyzing 27 Chinese cross-border M\&A activities that took place in the Shanghai and Shenzhen stock markets in 2000-2004, Agyenim et al. (2008) find that the deals create value for Chinese acquiring firms. Other studies (e.g. Li 2007; Young et al. 1996) also report that firms experience changes in market value and brand enhancement as they venture abroad. Chen and Young (2010) use event-study methods to show that firms who announce cross-border M\&A deals experience a positive abnormal return, but such positive return is significantly reduced when the government is the majority owner of the acquisitions. Recent research has also explored the indirect and/or mediating effects of ICF on firm performance, something missing from earlier work in the area. For example, Zhou (2007) and Cardoza and Fornes (2009) find that Chinese SMEs enjoy increased market return and visibility over those domestically oriented firms. In addition, Zhou et al. (2007) measure entrepreneurial action using a social network approach. Finally, several studies (e.g. Lau et al. 2010; Soderman et al. 2008) provide empirical evidence of the importance of international activity to firm performance by studying the effect of both market and the ICF on firm performance, such as gross profit margin and changes in market share.

\section{Directions for future research}

By means of a qualitative content analysis, this review highlighted the significant progress that has been made in the ICF field during the past two decades (1991-2010) and also provided an integrative model of how this research fits into the overall study of the ICF, as shown in Figure 1. This substantive and critical review also revealed a number of areas of research that need to be addressed and extended. In this section, we comment on a few of the most promising streams by specific discussion of the three categories of analysis - antecedents, processes and outcomes of the ICF - as examined in the previous section. In particular, we reflect on extant contributions and offer several recommendations for future conceptual, empirical and methodological research in the ICF. We begin with theme-specific recommendations in the three categories of analysis and then proceed by offering some generic recommendations which may apply across all the major themes of this research stream.

\section{Antecedents of ICF}

Beyond that typical call to collect better data (i.e. new sources, cleaner measures and longitudinal data), challenges remain for researchers interested in the antecedents of the ICF. First, there needs to be a more careful linkage between the variables used and theories. Many studies include firm-level variables in an ad hoc manner. As a result, the statistical inferences to theory become obfuscated (see also Yang et al. 2006). For qualitative case studies, scholars 
might pay more attention to the rigor of field research, particularly in terms of internal validity and construct validity (Gibbert et al. 2008). After all, the extant case studies of the ICF are most likely due to a lack of both logical validity regarding the causal relationships between the case analysis and results (i.e. internal validity) and quality of the conceptualization or operationalization of the relevant concept (i.e. construct validity). Research into firm resources, institutional factors as well as social and business network ties that stimulate or act as constraints on the ICF can be greatly aided by parallel development in RBV and institutional theory perspectives (e.g. Oliver 1997). While some of this has begun (e.g. Deng 2009; Rui and Yip 2008; Yang et al., 2009b), we expect this to be one of the most fruitful areas for the ICF research. Incorporating institutional and particularly normative and cultural factors, which are largely ignored in the extant literature and firms' strategic actions in response to the Chinese unique institutional characteristics, helps to apply the general theory of FDI into a specific dynamic context (Buckley et al. 2007; Shenkar 2004). In essence, as global investment knowledge can be gained through context-embedded, context-bounded or contextspecific conceptualization (Tsui 2004), the rapid social, institutional and cultural transformation in China, the largest emerging market in the world, could present unprecedented opportunities to apply general FDI theories and possibly develop new theories grounded in a new institutional and cultural context.

In addition, in studying the Chinese internationalization issue, several studies have carefully considered firm-firm links and firm-government links (Hong and Sun 2006; Yiu 2011; Zhou et al. 2007), however, the link between and interactions of inward FDI and OFDI of Chinese firms are essentially ignored. But one of the most distinctive differences between Chinese MNEs and other emerging market MNEs is that almost all the Chinese MNEs had conducted various international engagements with foreign investors in China before investing overseas. The cumulative benefits of inward FDI have apparently fostered or helped to accelerate subsequent OFDI by Chinese MNEs (Child and Rodrigues 2005; Deng 2009), and such unique and dynamic linkage warrants much scholarly inquiry in the future. These mechanisms have implications for industry studies which look at the propensity of Chinese MNEs to invest overseas, institutional studies which look at how formal and informal mechanisms shape the ICF and global competition, as well as the salience of an acquisition deal and timing, as brought about by changes in economic, institutional, competitive environment or global financial crisis (Luo and Rui 2009; Shenkar 2004).

Finally, more data need to be gathered about managerial preferences and decisions about international endeavors, not only by prominent Chinese overseas-investing firms, but also by a large number of SMEs. While a handful of studies (e.g. Deng 2009; Liu et al. 2008) look at managerial decisionmaking, the vast majority operates at the firm or industry level of analysis. Given the importance of the upper echelons in strategy making (Carpenter et al. 2004; Hambrick and Mason 1984) and the early indicators of the importance of top management orientation and preference to the ICF, further work in this area is clearly needed. Such research is particularly promising, given that driving forces behind the majority of most world-known Chinese MNEs are their legendary Chinese CEOs, including Lenovo's Liu Chuanzhi, Huawei's Ren Zhengfei and Haier's Zhang Ruimin, who are retiring or will be retiring in the next five years. The transition from the first generation of legendary CEOs to less authoritative second generation of corporate leaders is deemed to have profound impacts on the international strategies of Chinese firms. After all, corporate governance in China is still not institutionalized, and legendary CEOs continue to play a disproportionally crucial role in the strategic decision and choice of Chinese firms (Ge and Ding 2008; Li 2007; Tsui et al. 2004). Continuing with the theme of top managerial influence, it might be highly fruitful for researchers to investigate whether the contribution patterns of firms matched those made by their top managers in the ICF as well as the process by which the top managers affect firm performance. By focusing on the microfoundations of global competitive advantages of Chinese MNCs, researchers could relate developing context-specific studies to global strategic management, thereby achieving much academic legitimacy of the ICF beyond the IB field.

\section{Processes of ICF}

International expansion needs to be managed carefully, especially after a certain level of internationalization is achieved (Buckley and Ghauri 1999). An area for future research on the processes of the ICF involves extending the behaviors aimed merely at international strategies to those aimed at 
the dynamic capability of firms, since the sustained competitive advantage of Chinese MNEs lies in their ability to simultaneously leverage core competences at home and explore new opportunities abroad in an integrated fashion (Luo and Tung 2007; March 1991). Research on the ICF must explore whether Chinese MNEs possess and, most importantly, build their dynamic capability, which allows them to deploy, transfer and manage geographically dispersed critical resources for sustained success in global competition (Luo 2000; Teece et al. 1997). As an important form of dynamic capability, absorptive capacity (Cohen and Levinthal 1990; Zahra and George 2002) is particularly critical for a Chinese firm to truly acquire a target firm's knowledge and expertise and enhance its knowledge development (Deng 2010). It is one thing to buy new knowledge, but it is another to absorb this knowledge and reflect it throughout the entire operation and into successful commercial ends. From the dynamic capability perspective, the ICF may contribute to the building of firm competitive advantages rather than merely being an outcome of existing advantages (Luo 2000). The development of Chinese OFDI is highly dynamic. When more firms have accumulated multiple FDI entry experiences, research may apply a more dynamic approach by linking a firm's current FDI entry mode choice decision to prior business and investment practices of themselves and benchmark firms.

From the organizational learning perspective (Vermeulen and Barkema 2001), we need to understand how Chinese firms design their organization, balance the headquarter-subsidiary relationship, and cope with foreign culture. Furthermore, we need to examine the interaction between Chinese MNEs and the institutions ('game-rules') of the global marketplace (e.g. Antkiewicz and Whalley 2007; Globerman and Shapiro 2009). For example, what impact will Chinese firms have on the institutions of the global marketplace? How do the global institutions affect Chinese MNEs? How will corporate governance improve in Chinese firms as they compete in global markets, and as Chinese domestic institutions develop?

Furthermore, numerous opportunities remain for researchers to consider how the ICF as a process can happen. For example, what are the subsidiary structures and roles that a firm needs in order to integrate its international expansion activities with capability building? How are cultural and other institutional factors related to expatriate management and know- ledge absorption? ${ }^{2}$ What types of organizational design, governance and incentives can be used to co-ordinate foreign subsidiary activities with other corporate activities? Regarding how to deal effectively with the institutional environments at the host country, what we see is a melding between the ICF and corporate social responsibility (CSR). The rise of global awareness CSR is relevant to the ICF in terms of numerous research questions (Carroll and Shabana 2010; Li et al. 2010). For instance, in the host country, are the Chinese SOEs conducting more CSR activities or conducting them more successfully than others because of the nature of state ownership? Corporate social responsibility in the host country may also become a strategically important weapon by altering international competition or corporate political actions such that it attracts allies and neutralizes rivals (Carroll and Shabana 2010; Globerman and Shapiro 2009; Li et al. 2010). In a study of the indigenous conceptual dimensions of Chinese CSR, for example, researchers could concentrate on exploring whether the widely accepted CSR dimensions in western countries have embodiments in Chinese international expansion in both developed and developing markets, and how the success or failure of Chinese MNCs worldwide is affected by the use of indigenous management techniques of their CSR dimensions. In this manner, a firm's social activities become new forms of the ICF for sustainable competition advantage building.

\section{Outcomes of ICF}

Measuring international outcomes in meaningful ways is a major challenge for scholars of the ICF. Research to date has provided only a fragmented and incomplete picture of the ICF outcomes. The overwhelming majority of performance variables refer to the measurement of economic or financial performance such as wealth creation, market capitalization and product sales, whereas measurement of corporate goal achievements and overall competitiveness is significantly underrepresented. In the aggregate, research using cross-sectional designs has demonstrated a positive relationship to economic performance (Cardoza and Fornes 2009; Zhao et al. 2010), but little or no research has taken a fine-grained approach to uncover important contingency relationships. In addition, researchers (e.g. Morck et al.

\footnotetext{
${ }^{2} \mathrm{We}$ are grateful to one of the reviewers for mentioning this potentially important research question.
} 
2008; Yeung and Liu 2008) clearly indicate the fallacy of economic benefits to constitute the only relevant outcome of the ICF, since most international activities by Chinese firms never have measurable economic outcomes or figures in the short term (e.g. Chan 1995; Kim 2006; Ning 2009). Relatedly, even if we can establish a given economic figure that is important to a firm, the models that link the ICF to the economic figures often fail to find a statistically significant relationship (see also Yang et al. 2006; Zhao et al. 2010). Therefore, more consideration needs to be made to non-economic outcomes, such as how Chinese firms' competitive advantages are enhanced, how their brands are recognized regionally or worldwide, and how the acquired resources (e.g. brand and innovation) are absorbed and put into successful commercial ends. Researchers should also focus on a series or portfolio of firm investment decisions, such as the sequential outcomes for a firm or industry spanning a period of time. A promising area is the research on co-evolution using longitudinal studies; that is, can and how do Chinese firms alter international strategies or institutional venues in order to maximize an overall institutional payout?

Future studies may choose managers' subjective assessment of corporate goal achievement, the most commonly used performance measure in the IB field (Knoerich 2010; Yang et al. 2006). Scholars may also examine the evaluations of managers from the parent companies as well as of foreign subsidiary managers to increase the overall accuracy of this measure. In addition, scholars may interview managers not only within the Chinese firm, but outside the investment and public affairs departments, as to their evaluation of the firm's international efforts in their businesses (Ning 2009). Striving for better outcome measures is not limited to scholars; practitioners, too, are searching for better methods to value international activities. In short, future studies should clearly define the key contingencies surrounding the performance effects of the ICF and investigate both subjective and objective measures so as to increase the validity of these measurements and make results robust.

\section{Reciprocal and multi-level analysis in ICF}

As discussed in the previous section, there are some studies in the ICF which analyze how antecedents influences processes and how processes influence outcomes, whereas most studies directly relate antecedents and outcomes. Most of this 'outcome-driven' research strives to explain the scope, extent, patterns and performance implications of ICF and to identify 'success factors' that make a Chinese firm internationalize earlier, with a better performance or with greater geographical coverage. As shown in Figure 1, there is the possibility of both processual and causal relationships and the potential for reciprocity between categories. However, the opposite route is very scarce, and so far does not exist in the extant literature. Future studies should consider both positive and negative feedback loops. Because little attention has been paid to these longitudinal and reciprocal relationships between the various outcome drivers and outcome measures and processes, they offer a fertile area for future research. Specifically, from an organizational success or failure perspective (Mellahi and Wilkinson 2004), future work could study the outcome of the international process, and link this outcome to the intensity of the firm's international efforts. Chinese firms may fail to manage resources appropriately, so it would be interesting to study how the firm's capability to make the 'right' decisions along the international process affects the outcome of this process and thus codetermines both the extent of internationalization and the extent of wealth creation (Lu et al. 2010; Ning 2009).

A study of such a complex process would probably involve more than one unit of analysis (Gammeltoft et al. 2010; Hitt et al. 2007). Yet almost all the articles focus on one isolated level of analysis and are therefore unable to recognize important causal connections which may exist among Chinese unique institutional environments, the provision of resources, firm capabilities and wealth creation (e.g. Luo and Rui 2009). As a holistic depiction, Figure 1 does not demonstrate the exact connection between the different levels of analysis, but is intended to signal the need for work that embraces interactions among the three categories and multilevel influence of outcomes. In contrast with studies primarily at one level of analysis, multilevel studies of this type have the potential to shed light on the 'black box' which intervenes between top management's intent and the realized strategy (Hitt et al. 2007). The ICF is cross level in nature, and a cross-level analysis of multiple influences on Chinese international behaviors is clearly needed (Deng 2009; Gammeltoft et al. 2010). Finally, given the present state of ICF literature, we strongly believe that initial theory-building, rather than theory-testing, work is paramount to arrive at a body of interdisciplinary and multi-level understanding of the ICF before more elaborate theory can be 
deducted and tested. Such an approach is more likely to produce scholarly works that are of great potential consequence and may 'identify compelling empirical patterns that cry out for future research and theorizing. They might be rich qualitative descriptions of important, but unexplored phenomena that, once described, could stimulate the development of theory and other insights' (Hambrick 2007, p. 1350).

\section{Conclusions}

Using content analysis and carefully reviewing the accumulated knowledge on the ICF in terms of its antecedents, processes and outcomes in the past two decades (1991-2010), this paper identifies significant opportunities to expand the current literature. The rise in prominence of the ICF is evidenced by the growing acceptance of the topic across a broad range of research disciplines and explained by its relevance in addressing competitive and strategic concerns of the emergence of Chinese MNEs worldwide. Despite rapid growth of the ICF literature, particularly in the last five years, the research to date has been fragmented and piecemeal, and numerous theoretical and empirical areas of the ICF remain significantly underinvestigated. In particular, we find a dearth of studies on the processes of Chinese internationalization. We also notice a lack of empirical studies on the overall competitiveness of Chinese MNCs. As Chinese firms go increasingly global, the challenge for scholars is to keep in sight these important and intriguing developments as they continue to examine and model the antecedents, processes and outcomes of the ICF. The field would benefit from not only more longitudinal and qualitative work, but also multi-level studies providing richer insights and better understanding about the role of institutions and dynamic capability in the Chinese IB. As an important issue at the intersection of IB, strategic management and China studies with profound impacts on both theoretical development and global competitiveness, research on the ICF should be catapulted to the forefront of the research agendas of even more scholars worldwide.

\section{References}

Agyenim, B., Wang, Q. and Yang, T. (2008). Cross-border M\&As by Chinese firms. Thunderbird International Business Review, 50, pp. 259-270.
Alden, C. and Davies, M. (2006). A profile of the operations of Chinese multinationals in Africa. South African Journal of International Affairs, 13, pp. 83-96.

Alon, I. and McIntyre, J. (eds) (2008). Globalization of Chinese Enterprises. New York, NY: Palgrave Macmillan.

Alon, I., Chang, J., Fetscherin, M., Lattemann, C. and McIntyre, J.R. (eds) (2009). China Rules: Globalization and Political Transformation. Basingstoke: Palgrave Macmillan.

Antkiewicz, A. and Whalley, J. (2007). Recent Chinese buyout activity and the implications for wider global investment rules. Canadian Public Policy, 33, pp. $207-$ 226.

Armstrong, S. and Wilkinson, A. (2007). Processes, procedures and journal development: past, present and future. International Journal of Management Reviews, 9, pp. 81-93.

Athreye, S. and Kapur, S. (2009). Introduction: the internationalization of Chinese and Indian firms - trends, motivations and strategy. Industrial and Corporate Change, 18, pp. 209-221.

Barney, J. (1991). Firm resources and sustained competitive advantages. Journal of Management, 17, pp. 99-120.

Barney, J.B. and Zhang, S. (2009). The future of Chinese management research: a theory of Chinese management versus a Chinese theory of management. Management and Organization Review, 5, pp. 15-28.

Boisot, M.H. and Meyer, M.W. (2008). Which way through the open door? Reflections on the internationalization of Chinese firms. Management and Organization Review, 4, pp. 349-365.

Bonaglia, F., Goldstein, A. and Mathews, J.A. (2007). Accelerated internationalization by emerging markets' multinationals. Journal of World Business, 42, pp. 369383.

Bruton, G.D. and Lau, C.M. (2008). Asian management research: status today and future outlook. Journal of Management Studies, 45, pp. 636-659.

Buckley, P.J. and Ghauri, P.N. (eds) (1999). The Internationalization of the Firm. London: Thomson Business Press.

Buckley, P.J., Clegg, J., Cross, A.R., Liu, X., Voss, H. and Zheng, P. (2007). The determinants of Chinese outward foreign direct investment. Journal of International Business Studies, 38, pp. 499-518.

Buckley, P.J., Cross, A.R., Tan, H., Liu, X. and Voss, H. (2008). Historic and emergent trends in Chinese outward direct investment. Management International Review, 48, pp. 715-748.

Cai, G. (1999). Outward foreign investment. China Quarterly, 160, pp. 856-880.

Cardoza, G. and Fornes, G. (2009). The internationalization of SMEs from China. Asia Pacific Journal of Management (published online 20 October 2009, doi 10.1007/ s10490-009-9174-z. Available at http://www.springerlink. com/content/ah2h53630660372g/fulltext.pdf). 
Carpenter, M.A., Geletkanycz, M.A. and Sanders, G. (2004). Upper echelons research revisited. Journal of Management, 30, pp. 749-778.

Carroll, A.B. and Shabana, K.M. (2010). The business case for corporate social responsibility: a review of concepts, research and practice. International Journal of Management Reviews, 12, pp. 85-105.

Chan, H.L. (1995). Chinese investment in Hong Kong. Asian Survey, 35, pp. 941-954.

Chen, Y. and Young, M. (2010). Cross-border mergers and acquisitions by Chinese listed companies. Asia Pacific Journal of Management, 27, pp. 523-539.

Child, J. (2009). Context, comparison and methodology in Chinese management research. Management and Organization Review, 5, pp. 91-105.

Child, J. and Rodrigues, S.B. (2005). The internationalization of Chinese firms: a case for theoretical extension. Management and Organization Review, 1, pp. 381-410.

Cohen, M.W. and Levinthal, D.A. (1990). Absorptive capacity: a new perspective on learning and innovation. Administrative Science Quarterly, 35, pp. 128-152.

Cui, L. and Jiang, F. (2009a). FDI entry mode choice of Chinese firms. Journal of World Business, 44, pp. 434444.

Cui, L. and Jiang, F. (2009b). Ownership decisions in Chinese outward FDI. Asian Business \& Management, 8, pp. 301-324.

Cui, L. and Jiang, F. (2010). Behind ownership decision of Chinese outward FDI. Asia Pacific Journal of Management, 27, pp. 751-774.

Deng, P. (2004). Outward investment by Chinese MNCs: motivations and implications. Business Horizons, 47, pp. 8-16.

Deng, P. (2007). Investing for strategic resources and its rationale: the case of outward FDI from Chinese companies. Business Horizons, 50, pp. 71-81.

Deng, P. (2009). Why do Chinese firms tend to acquire strategic assets in international expansion? Journal of World Business, 44, pp. 74-84.

Deng, P. (2010). What determines performance of crossborder M\&As by Chinese companies? An absorptive capacity perspective. Thunderbird International Business Review, 52, pp. 509-524.

Duysters, G., Jacob, J., Lemmens, C. and Yu, J. (2009). Internationalization and technological catching up of emerging multinationals. Industrial and Corporate Change, 18, pp. 325-349.

Eisenhardt, K.M. (1989). Building theories from case study research. Academy of Management Review, 14, pp. 532550.

Fetscherin, M., Alon, I. and Johnson, J.P. (2010). Assessing the export competitiveness of Chinese industries. Asian Business \& Management, 9, pp. 401-424.

Frost, S. (2004). Chinese outward direct investment in Southeast Asia. Pacific Review, 17, pp. 323-340.
Gammeltoft, P., Barnard, H. and Madhok, A. (2010). Emerging multinationals, emerging theory: macro- and microlevel perspectives. Journal of International Management, 16, pp. 95-101.

Gao, G.Y., Murray, J.Y., Kotabe, M. and Lu, J. (2010). A 'strategy tripod' perspective on export behaviors. Journal of International Business Studies, 41, pp. 377-396.

Ge, G. and Ding, Z. (2008). A strategic analysis of surging Chinese manufacturers: the case of Galanz. Asia Pacific Journal of Management, 25, pp. 667-683.

Gebre-Egziabher, T. (2007). Impacts of Chinese imports and coping strategies of local producers: the case of smallscale footwear enterprises in Ethiopia. Journal of Modern African Studies, 45, pp. 647-679.

Gibbert, M., Ruigrok, W. and Wick, B. (2008). What passes as a rigorous case study? Strategic Management Journal, 29, pp. 1465-1474.

Globerman, S. and Shapiro, D. (2009). Economic and strategic considerations surrounding Chinese FDI in the United States. Asia Pacific Journal of Management, 26, pp. 163-183.

Hambrick, D.C. (2007). The field of management's devotion to theory: too much of a good thing? Academy of Management Journal, 50, pp. 1346-1352.

Hambrick, D.C. and Mason, P.A. (1984). Upper echelons: the organization as a reflection of its top managers. Academy of Management Review, 9, pp. 193-206.

He, W. and Lyles, M.A. (2008). China's outward foreign direct investment. Business Horizons, 51, pp. 485491.

Herbert, T., Alon, I. and Munoz, J. (2007). The globalizing Chinese business enterprise: the role of strategic fit. International Journal of Chinese Culture and Management, $\mathbf{1}$, pp. 4-21.

Hitt, M.A., Beamish, P.W., Jackson, S.E. and Mathieu, J.E. (2007). Building theoretical and empirical bridges across levels. Academy of Management Journal, 50, pp. 13851399.

Hong, E. and Sun, L. (2006). Dynamics of internationalization and outward investment: Chinese corporations' strategies. China Quarterly, 187, pp. 610-634.

Judge, T.A., Cable, D.M., Colbert, A.E. and Rynes, S. (2007). What causes a management article to be cited? Academy of Management Journal, 50, pp. 491-506.

Khanna, T. and Palepu, K.G. (2006). Emerging giants building world-class companies in developing countries. Harvard Business Review, 84, pp. 60-69.

Kim, J.C. (2006). The political economy of Chinese investment in North Korea. Asian Survey, 46, pp. 898916.

Knoerich, J. (2010). Gaining from the global ambitions of emerging economy enterprises: an analysis of the decision to sell a German firm to a Chinese acquirer. Journal of International Management, 16, pp. 177-191.

Krippendorff, K. (2004). Content Analysis: An Introduction to Its Methodology. Thousand Oaks, CA: Sage. 
Lau, C.M., Ngo, H.-Y. and Yiu, D.W. (2010). Internationalization and organizational resources of Chinese firms. Chinese Management Studies, 4, pp. 258-272.

Li, P.P. (2007). Toward an integrated theory of multinational evolution. Journal of International Management, 13, pp. 296-318.

Li, S., Fetscherin, M., Alon, I., Lattemann, C. and Yeh, K. (2010). Corporate social responsibility in emerging markets. Management International Review, 50, pp. 635-654.

Lieberthal, K. and Herberg, M.E. (2006). china's search for energy security: implications for U.S. policy. NBR Analysis, 17, pp. 5-42.

Lin, X. (2010). State versus private MNCs from China: initial conceptualizations. International Marketing Review, 27, pp. 366-380.

Liou, C.-S. (2009). Bureaucratic politics and overseas investment by Chinese state-owned oil companies: illusory champions. Asian Survey, 49, pp. 670-690.

Liu, L. and Tian, Y. (2008). The internationalization of Chinese enterprises. International Journal of Technology and Globalization, 4, pp. 87-102.

Liu, X., Buck, T. and Shu, C. (2005). Chinese economic development, the next stage: outward FDI? International Business Review, 14, pp. 97-115.

Liu, X., Wen, X. and Huang, X. (2008). Entrepreneurship and internationalization of indigenous Chinese privateowned firms. International Business Review, 17, pp. 488508.

Lu, Y., Zhou, L., Bruton, G. and Li, W. (2010). Capabilities as a mediator linking resources and the international performance of entrepreneurial firms in an emerging economy. Journal of International Business Studies, 41, pp. 419-436.

Luo, Y. (2000). Dynamic capabilities in international expansion. Journal of World Business, 35, pp. 355-378.

Luo, Y. and Rui, H. (2009). An ambidexterity perspective toward multinational enterprises from emerging economies. Academy of Management Perspective, 23, pp. 49-70.

Luo, Y. and Tung, R.L. (2007). International expansion of emerging market enterprises: a springboard perspective. Journal of International Business Studies, 38, pp. 481498.

Luo, Y., Xue, Q. and Han, B. (2010). How emerging market governments promote outward FDI: experience from China. Journal of World Business, 46, pp. 68-79.

Macpherson, A. and Jones, O. (2010). Editorial: Strategies for the development of International Journal of Management Reviews. International Journal of Management Reviews, 12, pp. 107-113.

March, J.G. (1991). Exploration and exploitation in organizational learning. Organization Science, 2, pp. 71-87.

Mathews, J.A. (2009). China, India and Brazil. Asian Business \& Management, 8, pp. 5-32.

Mellahi, K. and Sminia, H. (2009). Guest Editors' introduction: The frontiers of strategic management research. International Journal of Management Reviews, 11, pp. 1-7.
Mellahi, K. and Wilkinson, A. (2004). Organizational failure: a critique of recent research and a proposed integrative framework. International Journal of Management Reviews, 5, pp. 21-41.

MOFCOM (Ministry of Commerce, China) (2005). 2004 Statistical Communiqué on China's Overseas Foreign Direct Investment. Beijing: Ministry of Commerce.

MOFCOM (2009). 2008 Statistical Communiqué on China's Overseas Foreign Direct Investment. Beijing, China: Ministry of Commerce.

Morck, R., Yeung, B. and Zhao, M. (2008). Perspectives on China's outward foreign direct investment. Journal of International Business Studies, 39, pp. 337-350.

Ning, L. (2009). China's leadership in the world ICT industry: a successful story of its 'attracting-in' and 'walkingout' strategy for the development of high tech industries? Pacific Affairs, 82, pp. 67-91.

Niosi, J. and Tschang, F.T. (2009). The strategies of Chinese and Indian software multinationals. Industrial and Corporate Change, 18, pp. 269-294.

Nolan, P. and Zhang, J. (2002). Globalization challenge for large firms from developing countries. European Management Journal, 21, pp. 285-299.

North, D.C. (1990). Institutions, Institutional Change and Economic Performance. Cambridge: Cambridge University Press.

Obi, C.I. (2008). Enter the dragon? Chinese oil companies \& resistance in the Niger Delta. Review of African Political Economy, 35, pp. 417-434.

Oliver, C. (1997). Sustainable competitive advantage: combining institutional and resource-based views. Strategic Management Journal, 18, pp. 697-713.

Peng, M.W. (2003). Institutional transitions and strategic choices. Academy of Management Review, 28, pp. 275296.

Peng, M.W., Lu, Y., Shenkar, O. and Wang, D. (2001). Treasures in the China house: a review of management and organizational research on Greater China. Journal of Business Research, 52, pp. 95-110.

Rugman, A.M. and Li, J. (2007). Will China's multinationals succeed globally or regionally? European Management Journal, 25, pp. 333-343.

Rui, H. and Yip, G. (2008). Foreign acquisitions by Chinese firms: a strategic intent perspective. Journal of World Business, 43, pp. 213-226.

Sauvant, K.P. (2005). New sources of FDI: the BRICs. Journal of World Investment and Trade, 6, pp. 639709.

Schuler-Zhou, Y. and Schuller, M. (2009). The internationalization of Chinese companies. Chinese Management Studies, 3, pp. 25-42.

Scott, W. (2001). Institutions and Organizations, 2nd edn. Thousand Oaks, CA: Sage Publications.

Sethi, D. (2009). Is international business strategy global or regional? European Management Journal, 27, pp. 356365. 
Shenkar, O. (2004). One more time: international business in a global economy. Journal of International Business Studies, 35, pp. 161-171.

Soderman, S., Jakobsson, A. and Soler, L. (2008). A request for repositioning: the emerging internationalization of Chinese companies. Asian Business \& Management, 7, pp. 115-142.

Sutherland, D. (2009). Do China's 'national team' business groups undertake strategic-asset-seeking OFDI? Chinese Management Studies, 3, pp. 11-24.

Taylor, R. (2002). Globalization strategies of Chinese companies. Asian Business \& Management, 1, pp. 209225.

Teagarden, M. and Cai, D. (2009). Learning from dragons who are learning from us. Organizational Dynamics, 38, pp. 73-81.

Teece, D., Pisano, G. and Shuen, S. (1997). Dynamic capabilities and strategic management. Strategic Management Journal, 18, pp. 509-533.

Tolentino, P.E. (2010). Emerging multinationals: outward foreign direct investment from emerging and developing economies. Journal of International Management, 16, pp. 102-120.

Tsui, A.S. (2004). Contributing to global management knowledge: a case for high quality indigenous research. Asia Pacific Journal of Management, 21, pp. 491-513.

Tsui, A.S., Nifadkar, S.S. and Ou, A.Y. (2007). Crossnational, cross-cultural organizational behavior research. Journal of Management, 33, pp. 426-478.

Tsui, A.S., Schoonhoven, C., Meyer, M.W., Lau, C.M. and Milkovich, G. (2004). Organization and management in the midst of societal transformation. Organization Science, 15, pp. 133-144.

UNCTAD (2006). World Investment Report 2006: FDI from Developing and Transition Economies. New York: UNCTAD.

Vermeulen, F. and Barkema, H. (2001). Learning through acquisitions. Academy of Management Journal, 44, pp. 457-476.

Voss, H., Buckley, P. and Cross, A. (2010). The impact of home country institutional effects on the internationalization strategy of Chinese firms. Multinational Business Review, 18, pp. 25-48.

Wang, M.Y. (2002). The motivations behind China's government-initiated industrial investment overseas. Pacific Affairs, 75, pp. 187-206.

Warner, M., Ng, S. and Xu, X. (2004). Late development's experience and the evolution of transnational firms in the People's Republic of China. Asia Pacific Business Review, 10, pp. 324-345.

Weber, R.P. (1990). Basic Content Analysis. Thousand Oaks, CA: Age.

Werner, S. (2002). Recent developments in international management research. Journal of Management, 28, pp. 277-305.
Witt, M.A. and Lewin, A.Y. (2007). Outward foreign direct investment as escape response to home country institutional constraints. Journal of International Business Studies, 38, pp. 579-594.

Wong, J. and Chan, S. (2003). China's outward direct investment: expanding worldwide. China: An International Journal, 1, pp. 273-301.

Wright, M., Filatotcheve, I., Hoskisson, R.E. and Peng, M.W. (2005). Strategy research in emerging economies. Journal of Management Studies, 42, pp. 1-33.

Wu, F. (2005). The globalization of corporate China. NBR Analysis, 16, pp. 5-30.

Wu, F. and Seah, A. (2008). China Investment Corporation faces formidable challenges. China Business Review, July-August, pp. 56-59.

Wu, F. and Sia, Y. (2002). China's rising investment in Southeast Asia. Journal of Asian Business, 18, pp. 41-61.

Yamakawa, Y., Peng, M.W. and Deeds, D. (2008). What drives new ventures to internationalize from emerging to developed economies? Entrepreneurship Theory and Practice, 32, pp. 59-82.

Yang, M. (2009). Isomorphic or not? Chinese Management Studies, 3, pp. 43-57.

Yang, X., Jiang, Y., Kang, R. and Ke, Y. (2009a). A comparative analysis of the internationalization of Chinese and Japanese firms. Asia Pacific Journal of Management, 26, pp. 141-162.

Yang, X., Lim, Y., Sakurai, Y. and Seo, S. (2009b). Internationalization of Chinese and Korean firms. Thunderbird International Business Review, 51, pp. 37-51.

Yang, Z., Wang, X. and Su, C. (2006). A review of research methodologies in international business. International Business Review, 15, pp. 601-617.

Yeung, H. and Liu, W. (2008). Globalizing China. Eurasian Geography and Economics, 49, pp. 57-86.

Yiu, D.W. (2011). Multinational advantages of Chinese business groups: a theoretical exploration. Management and Organization Review, 7, pp. 249-277.

Yiu, D.W., Lau, C.M. and Bruton, G.D. (2007). International venturing by emerging economy firms. Journal of International Business Studies, 38, pp. 519-540.

Young, S., Hood, N. and Lu, T. (1998). International development by Chinese enterprise. Long Range Planning, 31, pp. 886-893.

Young, S., Huang, C.H. and McDermott, M. (1996). Internationalization and competitive catch-up processes. Management International Review, 36, pp. 295-314.

Yuan, L. and Pangarkar, N. (2010). Inertia versus mimicry in location choices by Chinese multinationals. International Marketing Review, 27, pp. 295-315.

Zahra, S.A. and George, G. (2002). Absorptive capacity: a review, reconceputalization and extension. Academy of Management Review, 27, pp. 185-204.

Zeng, M. and Williamson, P. (2003). The hidden dragons. Harvard Business Review, 81, pp. 92-99. 
Zhan, J.X. (1995). Transnationalization and outward investment. Transnational Corporations, 4, pp. 67-100.

Zhao, W., Liu, L. and Zhao, T. (2010). The contribution of outward direct investment to productivity changes within China, 1991-2007. Journal of International Management, 16, pp. 121-130.
Zhou, L. (2007). The effects of entrepreneurial proclivity and foreign market knowledge on early internationalization. Journal of World Business, 42, pp. 281-293.

Zhou, L., Wu, W. and Luo, X. (2007). Internationalization and the performance of born-global SMEs. Journal of International Business Studies, 38, pp. 673-690. 